\title{
Bactericidal effect of photo-activated riboflavin using UVA
}

\author{
Viroj Wiwanitkit
}

Received: 20 November 2009/Accepted: 20 December 2009/Published online: 21 January 2010

(C) Springer-Verlag 2010

Editor,

I read the recent report on the bactericidal effect of photoactivated riboflavin using UVA with great interest [1]. Makdoumi et al. concluded that "Riboflavin photoactivation using UVA $(365 \mathrm{~nm})$ can achieve an extensive eradication of bacteria, and the combination is more potent in reducing bacterial number than UV alone [1]." Indeed, the effectiveness of this new technique is reported in a number of articles in the literature. Schrier et al. recently reported a similar finding on success in using this technique for in vitro killing of three important bacteria, S. aureus, MRSA, and $P$. aeruginosa [2]. Martin et al. noted that this technique was eeffective against $S$. aureus, $S$. epidermidis, $P$. aeruginosa, MRSA, MDRPA, and DRSP, but was ineffective on Candida albicans [3]. There are some concerns on the technique used and conclusion made by Makdoumi et al. First, the conclusion that the technique could achieve an extensive eradication of bacteria could not be established, but the conclusion can be specifically made with regard to the in vitro effect on $S$. aureus, $S$. epidermidis, $P$. aeruginosa. The other bacteria that are not investigated might have different responses to the technique. Second, the quality control in microbiological culture, preparation of stock, and final examination is not well-clarified, since the interference during these steps can modify the final outcome. In addition, there is also no control on the UVA source especially for the rate of exposure to the studied sample. Finally, the number of investigated experiments is still questionable for statistical significance. The repeatability and precision of the experimental procedure should also be discussed.

\section{References}

1. Makdoumi K, Bäckman A, Mortensen J, Crafoord S (2009) Evaluation of antibacterial efficacy of photo-activated riboflavin using ultraviolet light (UVA). Graefes Arch Clin Exp Ophthalmol Nov 18 [Epub ahead of print]

2. Schrier A, Greebel G, Attia H, Trokel S, Smith EF (2009) In vitro antimicrobial efficacy of riboflavin and ultraviolet light on Staphylococcus aureus, methicillin-resistant Staphylococcus aureus, and Pseudomonas aeruginosa. J Refract Surg 25(9):S799-S802

3. Martins SA, Combs JC, Noguera G, Camacho W, Wittmann P, Walther R, Cano M, Dick J, Behrens A (2008) Antimicrobial efficacy of riboflavin/UVA combination $(365 \mathrm{~nm})$ in vitro for bacterial and fungal isolates: a potential new treatment for infectious keratitis. Invest Ophthalmol Vis Sci 49(8):3402-3408

\footnotetext{
V. Wiwanitkit $(\bowtie)$

Wiwanitkit House, Bangkhae,

Bangkok, Thailand 10160

e-mail: wviroj@yahoo.com
} 